\title{
An assessment of flood emergency plans in England and Wales, France and the Netherlands
}

\author{
D Lumbroso ${ }^{1,2}, \mathrm{~K}$ Stone $^{3}$ and $\mathrm{F}$ Vinet $^{4}$ \\ ${ }^{1}$ Laboratoire Central des Ponts et Chaussées, BP 4129, 44341 Bouguenais, France \\ ${ }^{2}$ HR Wallingford, Howbery Park, Wallingford, Oxfordshire OX10 8BA, UK \\ ${ }^{3}$ Deltares, Rotterdamseweg 185, Delft, The Netherlands \\ ${ }^{4}$ Gestion des Sociétés des Territoires et des Risques (GESTER), University of Montpellier III, France
}

Published in the Journal of Natural Hazards, Volume 58, Number 1 (2011), pp341-363

\section{Abstract}

This paper details research carried out in England and Wales, France and the Netherlands on the evaluation of emergency plans for floods. To assess the flood emergency plans 22 metrics were developed. These metrics covered a range of issues from the aims and objectives of the plan to training and exercises. A number of emergency plans in each of the three countries were reviewed using these metrics and online surveys of emergency planners were carried out. The objectives of the surveys were to establish what information emergency planners believe is useful to incorporate in emergency plans and at what level of detail.

The developed metrics and survey of end users provided a basis to compare emergency plans. The effectiveness of an emergency plan is difficult to measure and end users often stated that this can only be assessed accurately after a plan has been used. Many emergency planners indicated that a well defined description of the roles, responsibilities and communication is essential for a plan to be effective. These aspects tended to be well covered in the evaluated plans. However, other more technical aspects such as accessibility of roads, evacuation, depiction of the flood hazard and impacts of floods on critical infrastructure can be considerably improved. The main challenge for emergency planners is to avoid filling plans with generic text and to provide an appropriate level of specific detail in the plan whilst ensuring the "usability" of the plan.

\section{Keywords}

assessment; emergency plans; metrics; floods

\section{Introduction}

During the last two decades flood risk management policies in many European Union countries have evolved significantly (Tapsell \& Ball, 2007). The paradigm of attempting to reduce the flood risk as much as possible purely through structural measures has progressively been overtaken by a more holistic approach to flood risk management (Lagadec, 2002). The management of the residual risks has become a priority for natural hazards such as floods. This shift in paradigm has led to more effort being focused on producing emergency 
plans specifically for floods. The overarching aim of these plans is to allow communities to survive and recover as rapidly as possible from the effects of inundations.

Recently, the emergency management of floods in Europe has placed increasing importance on developing enhanced preparedness capacities. In this regard, the concept of emergency management has shifted from a primary focus on responding to the flood and its impacts to one of increased attention to communities becoming more resilient to the impacts of floods. The capacity to respond effectively remains important, however, emergency responders and planners are looking more intently at the earlier stages of emergency planning and how plans for floods can be improved. It is also important that these plans include preparations for low probability, high consequence events (Jonkman et al, 2005, Jonkman, 2007). In June and July 2007 England and Wales was hit by widespread flooding. A review of these floods found that the amount of information made available at the local level for emergency response planning was insufficient (Pitt, 2007). France has also been subject to a number of extreme floods over the past decade. The quality of the response to an emergency is only as effective as the reliability of the information which is available to inform the response (MacFarlane, 2005).

This paper describes research carried out in England and Wales, France and the Netherlands detailing how emergency plans for floods can be evaluated and thus improved. An emergency plan may be defined as a "coordinated set of protocols for managing an adverse event, whether expected or untoward in the future" (Alexander, 2005). Recent decades have seen significant increases in the number, scope and complexity of incidents and disasters. The process of constructing a written emergency plan is of great benefit to organisations that have to respond to an emergency (Fischer III, 1996). It is now generally agreed that for places that are significantly at risk of hazards authorities should be required to produce emergency plans (Alexander, 2005). Grunfest and Handmer (2001) also note that emergency planning is the best way to significantly reduce the loss of life from floods especially for flash floods where lead times are short.

The assessment of crisis management processes and emergency plans is fundamental for their improvement; however, most theorists and practitioners pay only a passing reference to the process (Heath, 1998). Existing literature to assess emergency plans is often unhelpful and there have been few attempts to establish the principles of evaluating plans beyond summary checklists (Barton, 1993; Albrecht, 1996; Heath, 1998).

The production of emergency plans in Europe specifically focused on floods is a relatively recent phenomenon. In England and Wales and the Netherlands, Acts of Parliament passed in 2004 have acted as a catalyst to the formulation of emergency plans for flooding. In France an Act passed in 2005 paved the way for the production of local level emergency plans. In all three countries emergency planning for floods is initially the responsibility of local government. Although regional and national flood emergencies cannot be managed exclusively at a local government level the essential remedy to an emergency situation is almost inevitably applied at a local scale (Drabek and Hoetmer, 1991).

There are several reasons put forward as to why the evaluation of emergency plans for floods has until recently received such little attention and why the plans themselves may be in need of improvement. It has been postulated that this is because:

1. Stakeholders are still evolving principles and procedures for the effective management of flood emergencies Heath (1998). There is also a consensus that emergency management is not a fully fledged profession (Crews, 2001).

2. The objectives of what is being evaluated are often blurred Heath (1998). 
3. There is often a lack of openness when evaluating either the preparation for emergencies or post-event debriefings as a result of stakeholders feeling threatened by criticism or being vulnerable to having the blame for any perceived failures assigned to them Heath (1998).

4. Emergency plans specifically for floods are a relatively recent development and hence it is only in the past two or three years that a requirement for their evaluation has emerged.

Research carried out by Alexander has found that there is an "enormous variety and lack of homogeneity" amongst emergency planning documents in many parts of the world. Alexander postulates that this implies that there is "a shortage of adequate standards [or metrics] for creating, evaluating and approving emergency plans" (Alexander, 2002, 2003, 2005) and that "virtually no appropriate standards seem to exist" (Alexander, 2005). Alexander also found that there was little in the way of metrics via which the "fitness for purpose" of emergency management plans can be developed.

Figure 1 illustrates that the demand for information during an emergency usually accelerates at a rate far above that of supply. This leads to what may be termed a "demand-provision gap" (MacFarlane, 2005) or "information gap". In most cases this is not because the information does not exist, but because it is not actually included in an emergency plan and thus often not accessible at the point and time of need. The key question that needed to be addressed in these three countries was how it can be established if emergency plans for floods are "complete" in order to reduce the information gap as much as possible. A first step in this process was to address the following questions:

- Which elements are currently being addressed within emergency plans and at what level of detail?

- What makes an emergency plan for floods effective in the eyes of the primary stakeholders?

These questions were researched via the development of metrics, an online survey of stakeholders responsible for producing emergency plans and a review of flood emergency plans.
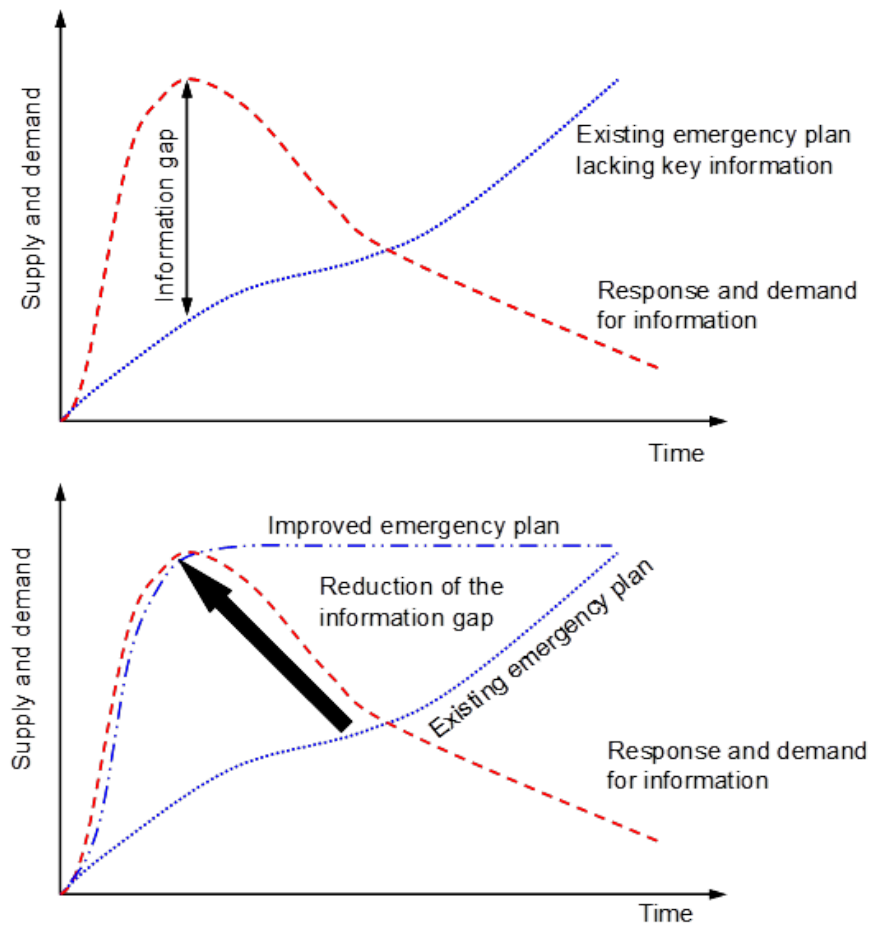

Figure 1: The "information demand provision gap" during an emergency event

(Adapted from MacFarlane, 2005) 


\section{Background to the emergency planning for floods in England and Wales, France and the Netherlands}

In all three countries there are tiers of emergency planning ranging from national, regional to local plans. There are generic plans that focus on strategic planning covering issues such as organisation and responsibility, communication and evacuation. These plans cover other risks besides flooding. In England and Wales and the Netherlands there are underlying plans that focus on flooding. Emergency plans in France focus on a range of different hazards, including technological hazards, although in many areas flooding is the most important threat. The background to emergency planning for floods in each country is discussed below.

\subsection{England and Wales}

Flooding is a major natural hazard in the UK. In total, around 5.6 million properties in England and Wales, or one in six properties, are at risk of flooding. More than 5.3 million people live and work in 2.4 million properties that are at risk of flooding from rivers or the sea, one million of which are also at risk of surface water flooding. A further 2.9 million properties are susceptible to surface water flooding alone (Environment Agency, 2009a, 2009b). Five per cent of England's population lives in the 2,200 $\mathrm{km}^{2}$ of land most at risk from flooding by the sea, while $10,000 \mathrm{~km}^{2}$ is threatened by flooding from rivers. In all, about $10 \%$ to $15 \%$ cent of urban areas and about half the best agricultural land is at risk (Tunstall et al, 2004).

In June and July 2007 over 55,000 homes and 6,000 businesses were flooded as the result of widespread flooding and the related insurance claims were of the order of $£ 3$ billion (ABI, 2007). The floods had a significant impact on critical infrastructure over 100 sewage treatment works in the Midlands were affected. In Gloucestershire, the inundation of a water treatment plant left over 300,000 people relying on bottled water for several weeks and power supplies for over 40,000 homes were interrupted while temporary flood defences were installed at an electricity sub-station. Near Rotherham, the threat of failure of the Ulley Dam following the June 2007 rainfall was a primary factor in the evacuation of around 1,000 people (Marsh and Hannaford, 2007).

Emergency planning in the UK is governed by the Civil Contingencies Act 2004. There is a hierarchy of emergency planning in the UK. Issues such as evacuation, communication and the setting up of rest areas are generally covered by generic plans. These plans are then referenced by the Multi-Agency Flood Plan (MAFP) that includes specific information on flooding.

MAFPs are produced by the Local Resilience Forum. There are currently 47 Local Resilience Forums covering England and Wales that are based on the administrative boundaries of the police. Each Local Resilience Forum has to consider the flood risk across the whole area for which it is responsible. However, for some areas the response arrangements that are set out in generic emergency places are sufficient to cover the particular area at risk. For areas where the risk is higher more detailed MAFPs are required (Environment Agency/DEFRA, 2008). To date there have been some 323 MAFPs produced in England and Wales (Foster, 2010). 


\subsection{France}

More than $40 \%$ of the 36,500 French communes are affected by floods and flooding is responsible for $80 \%$ of the damage attributable to French natural disasters (Pottier, 2005). It has been estimated that approximately 4.5 million people are at risk of flooding in France (Enjolras et al, 2008). In February 2010 the Atlantic storm named Xynthia caused extensive coastal flooding on the western seaboard of France resulting in 53 deaths and in June 2010 some 25 people were killed as the result of flash flooding in the south-west of the country (BBC, 2010; Hernu et al, 2010).

At a communal level in France there is the Plan Communal de Sauvegarde (PCS), i.e. "local protection plans". The PCSs were created to help municipalities take charge of the management of emergency planning at a local level (Direction De La Defense Et De La Securitie Civiles, 2004). It has been estimated that there are currently 5,000 PCSs in existence in France. In 2002 Lagadec remarked that "deep resistance was the dominant characteristic of preparing for crisis situations in France" (Lagadec, 2002). This statement is borne out to a certain degree by the amount of time it has taken to get less than half the PCSs in place.

The PCS is the first plan that is put into action when an emergency occurs. The PCS is activated by the mayor of each commune. French citizens expect the mayor and their representative at a commune level to be at the forefront of emergency management (Lagadec, 2002). At a departmental level there are plans that complement the PCS, which set out rescue and evacuation strategies. These plans are activated when an emergency becomes too difficult or large for local authorities to handle.

\subsection{The Netherlands}

International assessments of vulnerability to flooding present the Netherlands as one of the most vulnerable flood prone areas in the world (European Environment Agency, 2005; Alcamo et al, 2007). Until recently, Dutch flood risk management concentrated on preventing floods from happening, primarily through the construction of embankments, and emergency planning received little attention (ten Brinke et al, 2010).

The success of engineering projects to keep water out for over 50 years, such as the Deltaworks project, has resulted in public complacency. People do not believe that flooding will happen to them In the Netherlands, a survey conducted for the Ministry of the Interior found that only $3 \%$ of the population had made some preparations for flooding; $60 \%$ were not aware of the risks they face; and $80 \%$ felt safe in their environment (Pitt, 2007). Another recent evaluation of flood risk in the Netherlands showed that the country is not prepared for wide scale flooding and that of all the hazards, flooding poses the greatest societal risk (ten Brinke et al, 2008).

In the Netherlands safety is legally defined as a local responsibility. Local authorities are obliged to formulate emergency management plans for the potential risks within their area. Often flood risks are addressed on a regional scale through the cooperation of several municipalities and agencies involved in event management or within the context of the Safety Region. This is due to the fact that in the Netherlands the extent of a flood almost always exceeds the municipality boundaries. By October 2010 a new law on safety regions will become effective and by the end of 201025 Safety Regions should be operational.

A Safety Region is a regional cooperation of municipalities, police, fire brigades and health care organisations. Each Safety Region has to prepare a "crisis" or emergency management plan. Although the Bill has only recently been approved the majority of the 25 Safety Regions in the Netherlands have started drafting their emergency management plans many of which focus on flooding related issues. 


\section{Development of metrics to assess flood emergency management plans}

\subsection{The requirement for metrics}

McConnell and Drennan (2006) point out that in a world of tight public expenditure constraints and extensive state interventions such as health, education, transport and defence, emergency planning is low on the list of political priorities. As a consequence funding for emergency planning is often low. In 2004 a survey of emergency planners in the UK found that $70 \%$ of respondents spent less than $£ 100,000$ per annum on planning for emergencies (Prachett, 2004).

Civil protection by its nature is an area that can easily be neglected. Local government emergency planning has often been the poor relation of local services. It is something never needed until it is required (O'Brien \& Read, 2005). Although a Spending Review in the UK in 2004 doubled the amount of civil defence grant from $£ 19$ million to $£ 38$ million (HM Treasury, 2004), the reality is that emergency management at the local level will probably continue to be inadequately resourced not just in the UK, but also in France and the Netherlands, and therefore be unable to provide a service compatible with changing public expectations (O'Brien \& Read, 2005). Given the relatively low level of support for emergency planners, there is a requirement for a simple set of metrics by which emergency plans for floods can be evaluated and any gaps in the plans identified by the primary stakeholders (e.g. emergency planners, fire brigades and the police), many of whom are not experts in the field of flood risk management.

A metric may be defined as a measure for something; a means of deriving a quantitative measurement or approximation for otherwise qualitative phenomena. Many emergency managers have expressed a need for metrics and guidance as they are often uncertain about the quality and appropriateness of their plans (Alexander, 2005; Environment Agency/DEFRA, 2009; Heath, 1998). This was confirmed by many stakeholders in the three countries, responsible for formulating emergency management plans for floods, consulted as part of the research. The evaluation of flood emergency plans is important to identify strengths and weaknesses in different approaches, as well as an aid in documenting improvements (or deteriorations) made over time. For organisations responsible for producing and evaluating plans, structured methods for evaluating such plans can be of great value.

\subsection{The metric development process}

It is important that the emergency planning process for floods is based on carefully devised scenarios and on a clear understanding of community vulnerability considerations, appropriate triggers for emergency action and the necessary requirements for responses to emergencies (Australian Government, 2009). Flood risk varies from place to place. It is important to note that whether an emergency plan is "acceptable" will be based on an individual assessment. The metrics developed had to be:

- Applicable to all the three countries taking part in the research

- Able to be applied to emergency plans for floods at a range of geographical scales ranging from a regional to local level

- Generic but at the same time be clear and focused to avoid misinterpretation

- Measurable

- Realistic given the various constraints related to emergency planning 
The metrics were developed following a review of a wide variety of emergency plans and consultation with a range of stakeholders in the three countries and also drew upon recommendations made as the result of recent floods in England and Wales and France such as those detailed in the Pitt Review (2008), Poulard (2009), Tricot (2008) and reviews in the Netherlands (ten Brinke et al, 2008, 2010) and documents produced by HM Government (2006) and DEFRA (2010) in the UK.

Other sources were also used to aid in the development of the metrics. These included the lessons learnt from major flood emergency exercises such as Triton 04 that took place in 2004 based on an extensive flood affecting nearly half of England and Wales (Environment Agency/Defra, 2004). This exercise involved over 60 organisations and almost 1,000 participants (Young, 2005). In September 2009, hundreds of fire fighters and rescue personnel from across Europe took part in a large scale and very realistic exercise simulating Europe's "worst credible flood event", an extreme tidal surge in the North Sea affecting the Netherlands and England and Wales (Hayden, 2009). An evaluation of this exercise, carried out by Bereens and Schneider (2009), also provided a useful insight as to the form the metrics should take. The results of work from various Exchange Forums on flooding such as European exchange circle on flood mapping (EXIMAP, 2007) and the European exchange circle on flood forecasting (EXCIFF, 2007), that brought together primary stakeholders from the fields of flood risk management and emergency planning from 15 countries throughout Europe were also used to inform the development of the metrics.

The need and support for the metrics with the end users was assessed during their development. This was done through a series of consultations and workshops. The metrics that resulted from the research cover the following areas:

- Aims and objectives of plan

- Target audience and updating of the plan

- Details of previous floods, flood hazard maps and flood warning

- Flood risk to people

- Flood risk to residential property and businesses

- Flood risk to critical infrastructure (e.g. gas, electricity and water supply infrastructure, police, fire brigade, health care related buildings)

- Potential for Natural Hazard Triggering Technological Disasters (NaTech) hazards triggered by floods at industrial or other facilities

- Evacuation routes

- Shelters/Safe havens

- Relationship with complementary emergency plans detailed

- Communication with other agencies, the public and the media

- Assumptions made by the plan

- Plan activation

- Actions, roles and responsibilities

- Recovery

- Training and exercises

A detailed list of the metrics developed is given in Appendix A of this paper. 


\section{Assessment of the emergency plans}

The development of the metrics also allowed the plans to be "scored" in a quantitative manner. For example a score of "1"was given for an individual metric where there was a "Low level of detail"; "2" where the metric had an "Average level of detail" and " 3 " where the metric was seen to be "Detailed". If the average score of all the metrics is less then "2" then this indicates that there is "Room for improvement" in the plan. An average score above " 2 " indicates that the plan is "Acceptable" and that a score of three indicates that the plan is "Good".

The scoring range for the emergency plans was divided into five equally distributed bands between a score of 1 and 3 based on the average score of the metrics for each plan. The five bands in Table 1 tie in generally with other checklists that have been developed (e.g. Environment Agency et al, 2009). The "rating" of a plan from the scores is shown in Table 1.

Table 1: Scores for the emergency plan

\begin{tabular}{|c|c|}
\hline $\begin{array}{l}\text { Average } \\
\text { score }\end{array}$ & Description to determine the quality of the flood emergency management plan \\
\hline 2.6 to 3.0 & $\begin{array}{l}\text { There is little or no further information that could have been included in the plan. This } \\
\text { could be considered to be a "Good" plan with little room for improvement }\end{array}$ \\
\hline 2.2 to $<2.6$ & $\begin{array}{l}\text { There is some further information that could have been included in the plan to improve its } \\
\text { effectiveness. This could be considered an "Above average" plan. }\end{array}$ \\
\hline 1.8 to $<2.2$ & $\begin{array}{l}\text { Considerably more information could have been included in the plan to help improve it. } \\
\text { This could be considered an "Average" plan }\end{array}$ \\
\hline 1.4 to $<1.8$ & There is some information missing from the plan. There is "Room for improvement" \\
\hline 1.0 to $<1.4$ & $\begin{array}{l}\text { There is a large amount of additional information that could be included in the plan that } \\
\text { would help to improve it considerably. This could be considered a plan with "Considerable } \\
\text { room for improvement" }\end{array}$ \\
\hline
\end{tabular}

It is important to note that in the application of the metrics to assess flood emergency plans, if an item was not included but its omission was fully justified (e.g. because it was covered in a complementary plan), then the particular metric was assessed as being "Detailed".

Detailed reviews of 41 plans were carried out using the metrics. The following were assessed:

- 13 Multi-Agency Flood Plans (MAFPs) in England and Wales

- 14 Plan Communaux de Sauvegarde (PCSs) and two higher level supporting plans in France

- 11 Safety Region Plans in the Netherlands and a National Response Plan

Each plan was scored using the developed metrics. This resulted in an average score per emergency plan and per metric.

\subsection{Results of the assessment using the metrics}

Table 2 provides an overview of the results of the assessment of the emergency plans carried out using the developed metrics. The review of the plans found that there was often a lack of homogeneity between the emergency plans. Often the same information was expressed in significantly different levels of detail. In England and Wales, two MAFPs did not include flood hazard maps and did not state if these were readily 
available either in other plans or other forms (e.g. CD ROM or a secure web site). In the Netherlands many of the flood maps included in emergency plans had details of maximum water depths and velocities.

Many of the plans reviewed had what could be classed as a large amount of generic "cut and paste" text on flooding but had limited text on local or regionally specific issues. It appears from the research that many of the responders would like more specific information especially with regards to the nature of the flood hazard and the accessibility of roads to emergency services and other vehicles for different flooding scenarios. In many densely populated areas it would be relatively easy to develop such maps for different probabilities of flood events.

Table 2: The overall results of the scoring of the emergency plans per country

\begin{tabular}{|l|l|l|l|}
\hline $\begin{array}{l}\text { Average score of } \\
\text { plans }\end{array}$ & 1.9 & 1.9 & 1.7 \\
\hline $\begin{array}{l}\text { Average plan } \\
\text { score category }\end{array}$ & Average & Average & Room for improvement \\
\hline Range of scores & 1.3 to 2.3 & 1.1 to 2.4 & 1.2 to 2.3 \\
\hline
\end{tabular}

The 22 metrics developed broadly fall into six categories as follow:

1. Objectives, assumptions and target audience

2. Organization and responsibility

3. Communication

4. Flood hazard

5. Flood risk to receptors (e.g. people, buildings, critical infrastructure)

6. Evacuation

An overview of the results of the comparison of these metric groups for the three countries is given in Table 3 , with a comparison between the average metric scores for each country shown in Figure 2.

Metrics related to organisational aspects of the plan such as: plan activation; roles and responsibilities; communication with other agencies; and target audience and updating scored well in all three countries. However, the assumptions made by the plans did not appear to be well defined. Details of previous floods although covered reasonably well in England and Wales, and France were not covered well in the Netherlands; this is probably as a result of the fact there have been no major flood events in the Netherlands since 1953.

Metrics related to the possible impacts of floods on receptors such as businesses; critical infrastructure; people; vulnerable people and NaTechs (Natural Hazard Triggering a Technological Disasters) all scored well below average in all three countries as well as the metrics concerned with evacuation aspects. The metric covering the relationship between complementary plans in England and Wales scored "above average"; however, in France and the Netherlands this metric scored "below average" indicating that there may be a "disconnect" between different complementary plans and that if other plans are referenced there is often not a detailed link provided to them.

Figure 3 shows a graph of the average metric score for a plan against the number of pages in the plan. There is a relationship between total length of emergency plans, including appendices, and the mean metric score for England and Wales and to a lesser degree the Netherlands. One stakeholder who contributed to the research said that " $A$ simple plan without great detail, signposting where further information is, is 
preferable to a plan that includes all the information making it a bulky, dust gathering, document." However, the longest emergency plan reviewed in England and Wales stretched to 300 pages and was found by users to be "compact and the information in it was relatively easy to locate" following its use in an extreme flood event in November 2009. This may indicate that "ease of navigation" of the plan is likely to be more important than plan length. However, in France there appeared to be no relationship between the metric score and the plan length.

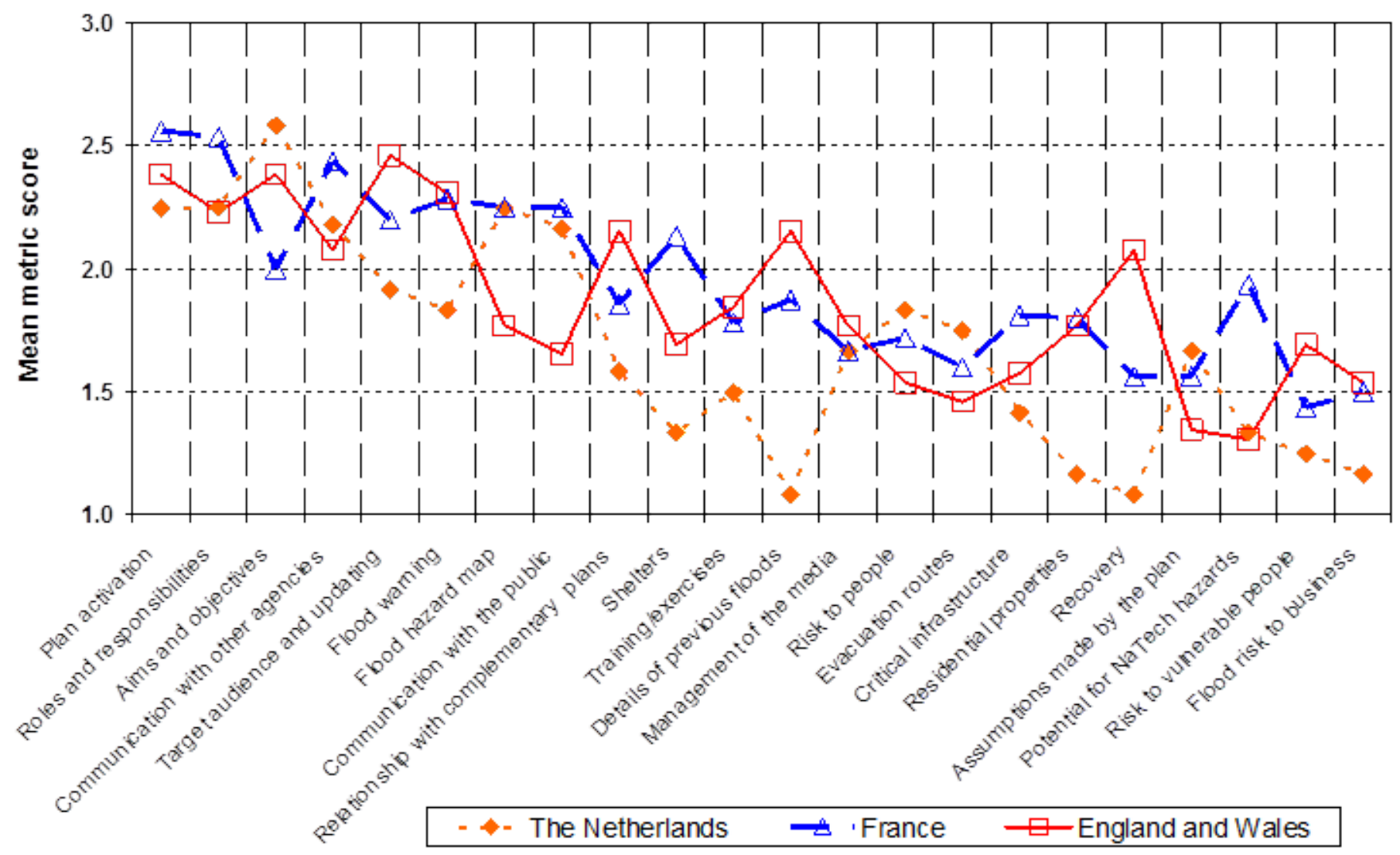

Figure 2: Comparison of the mean metric scores for the three countries 


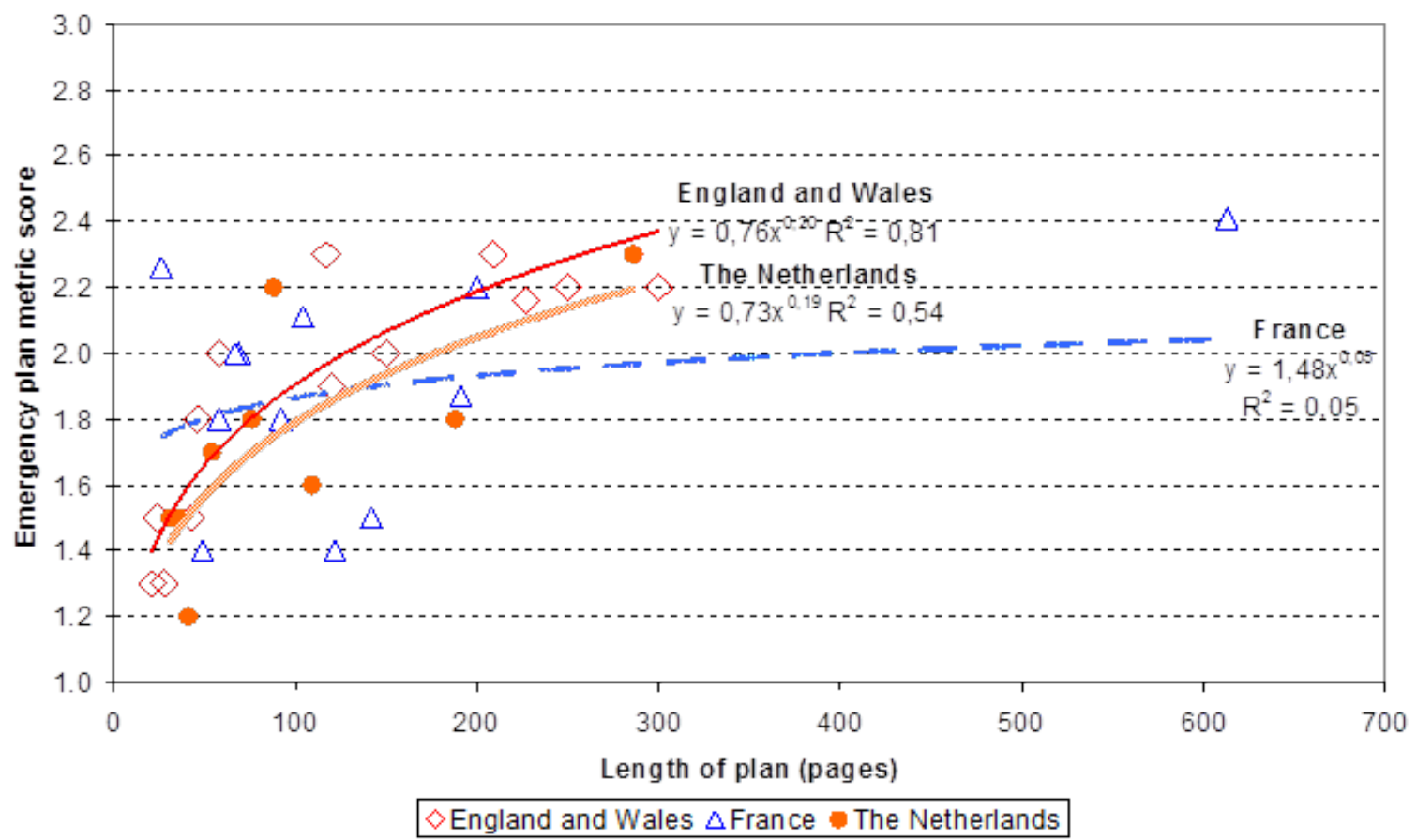

Figure 3: The relationship between the length of emergency plan and metric scores for England and Wales, France and the Netherlands

Table 3: The overall results of the scoring of the metrics per country

\begin{tabular}{|c|c|c|c|}
\hline Score category & England and Wales & France & The Netherlands \\
\hline Range of metric scores & 1.31 to 2.46 & 1.44 to 2.56 & 1.08 to 2.58 \\
\hline $\begin{array}{l}\text { Metric scores with } \\
\text { average and higher } \\
\text { scores }\end{array}$ & $\begin{array}{l}\text { Objectives, assumptions } \\
\text { and target audience } \\
\text { Organization and } \\
\text { responsibility } \\
\text { Flood hazard }\end{array}$ & $\begin{array}{l}\text { Organization and } \\
\text { responsibility } \\
\text { Communication }\end{array}$ & $\begin{array}{l}\text { Objectives, assumptions } \\
\text { and target audience } \\
\text { Communication }\end{array}$ \\
\hline $\begin{array}{l}\text { Metric scores are } \\
\text { "average", or where } \\
\text { there was a large } \\
\text { spread of scores }\end{array}$ & Communication & $\begin{array}{l}\text { Flood hazard } \\
\text { Objectives, assumptions } \\
\text { and target audience } \\
\text { Evacuation }\end{array}$ & $\begin{array}{l}\text { Flood hazard } \\
\text { Organization and } \\
\text { responsibility }\end{array}$ \\
\hline $\begin{array}{l}\text { Metrics scores falling } \\
\text { into the category "Room } \\
\text { for improvement" or } \\
\text { lower }\end{array}$ & $\begin{array}{l}\text { Flood risk to receptors } \\
\text { Evacuation }\end{array}$ & Flood risk to receptors & $\begin{array}{l}\text { Flood risk to receptors } \\
\text { Evacuation }\end{array}$ \\
\hline
\end{tabular}




\subsection{Results of the surveys of emergency managers}

An online survey was sent to stakeholders in the three countries. The questions focused on the requirement for information in the plan development stage, and its usefulness and required level of detail. In total 208 people responsible for formulating and contributing to emergency plans responded to the survey. This was made up of 95 people from England and Wales, 77 from France and 36 from the Netherlands. It is estimated that the survey reached the following approximate numbers of stakeholders: 350 in England and Wales; 250 in France; and 150 in the Netherlands. Table 4 gives a breakdown of the stakeholders who responded to the survey. In England and Wales, and the Netherlands most of the stakeholders responding to the survey worked for local authorities in an emergency planning role. In France the majority of the responders were from the fire service. This is because in 1884 the fire service was given responsibility for emergency services for all human disasters (Drouet, 1982). As a consequence it plays a larger part in emergency planning than in the other two countries.

Table 4: Breakdown of the types of stakeholders who responded to the survey

\begin{tabular}{|c|c|c|c|}
\hline \multirow[b]{2}{*}{ Type of organisation } & \multicolumn{3}{|c|}{ Percentage of responses } \\
\hline & $\begin{array}{l}\text { England and } \\
\text { Wales }\end{array}$ & France & The Netherlands \\
\hline $\begin{array}{l}\text { Emergency services (e.g. Fire and rescue services, } \\
\text { police) }\end{array}$ & $21.2 \%$ & $55.3 \%$ & $0 \%$ \\
\hline $\begin{array}{l}\text { Flood managers (e.g. flood forecasting, water } \\
\text { management organisations) }\end{array}$ & $2.4 \%$ & $9.2 \%$ & $0 \%$ \\
\hline Health (e.g. ambulance service) & $8.2 \%$ & $0.0 \%$ & $0 \%$ \\
\hline Local authority or council & $51.8 \%$ & $31.6 \%$ & $100 \%$ \\
\hline Transport (e.g. roads, railway) & $4.7 \%$ & $0.0 \%$ & $0 \%$ \\
\hline Utility (e.g. communications, electricity, gas, water) & $4.7 \%$ & $2.6 \%$ & $0 \%$ \\
\hline Other & $7.1 \%$ & $1.3 \%$ & $0 \%$ \\
\hline
\end{tabular}

The responders were asked to "score" the level of detail they felt there should be for a variety of subjects in an emergency management plan. The level of detail of the information was scored from 1 to 5 , with $1=$ "not detailed in the plan" and $5=$ "very detailed". The details of the results are briefly discussed.

\subsubsection{Metrics relating to objectives, assumptions and target audience, organization and responsibility and communication}

Plan activation had the highest required level of detail for the three countries. Many stakeholders who contributed to the research stated that for an emergency plan to be effective, clear triggers, often related to specific flood levels at specific places, were needed to invoke actions and responses. There seemed to be a broad consensus that there needs to be clear definitions and guidance on how and when plans are activated.

It is interesting to note that in the review of the MAFPs in England and Wales, issues related to plan activation, communication with other agencies and the media, relationship with complementary plans all scored relatively well. It would appear that issues related to communication and responsibilities are currently relatively well covered by MAFPs. It should be noted that the assumptions made by MAFPs were often not explicitly stated. 
In France information regarding communication can be classified in two groups. Information and communication required before the crisis such as target audience, plan activation and communication to public scored "above average". In contrast items related to the post disaster phase are often neglected.

\subsubsection{Metrics relating to flood hazard, receptors and evacuation}

From the review of the MAFPs in England and Wales using the developed metrics the level of detail of information relating to flood hazard, receptors and evacuation mostly fell into the category of either "room for improvement" or "considerable room for improvement". This would seem to suggest that apart from flood warning times there is not enough "relevant" information available to emergency planners to help them with the formulation of MAFPs.

In France flood hazard maps scored highly. Although in the two other countries many responders to the survey stated that they wanted flood maps that show information about depth and velocities of the flow, as well as detailed likely flow routes. The impacts of flooding on critical infrastructure were mentioned as being important by emergency planners; however, Figure 2 shows that the mean scores for this metric were low.

\section{Effectiveness of emergency plans}

As part of the survey the responders were asked to briefly list up to five criteria that they believed make a flood emergency management plan effective. The various responses for each country were grouped under generic headings. The top five generic responses are given in Table 5. In all three countries stakeholders indicated that for plans to be effective the roles and responsibilities should be clearly defined. One responder summed up that an effective flood emergency plan needed to have "Roles and responsibilities clearly spelt out and agreed (with no assumptions made by any organisation)".

The role of "trigger levels" also featured in many responses in all three countries. A trigger level can be defined as "an event causing the automatic invocation of a procedure". Many responders stated that for a plan to be effective clear triggers are needed to invoke actions and responses. Clarity, adaptability, accessibility and brevity of the plan were also mentioned by many responders as being important; however, as discussed above ease of navigation of a plan may actually play a more important part in its accessibility than its length.

Information on the flood hazard was also seen as very important. This is borne out by research carried out by Dymon (2003) that showed that maps for pre-event planning are essential to emergency management plans and that the lack of maps in plans causes problems. Responders stated that they would like to see the inclusion in plans of larger maps or maps showing more detail; maps highlighting "hotspots" and the inclusion of the flood maps on an integrated GIS system. Details of flood depths and velocities were also seen as important, as well as having a number of different flood scenarios.

Table 5: Criteria perceived by stakeholders to make a flood emergency plan effective

\begin{tabular}{|l|l|l|l|}
\hline Rank & England and Wales & France & The Netherlands \\
\hline 1 & Roles and responsibilities & Roles and responsibilities & Roles and responsibilities \\
\hline 2 & Triggers levels & Trigger levels & Information on the flood hazard \\
\hline 3 & $\begin{array}{l}\text { Information on the flood } \\
\text { hazard }\end{array}$ & $\begin{array}{l}\text { Information on the flood } \\
\text { hazard }\end{array}$ & Clarity and accessibility of plans \\
\hline
\end{tabular}




\begin{tabular}{|l|l|l|l|}
\hline Rank & England and Wales & France & The Netherlands \\
\hline 4 & $\begin{array}{l}\text { Clarity and brevity of the } \\
\text { plan }\end{array}$ & Adaptability and simplicity & Training in the use of the plan \\
\hline 5 & $\begin{array}{l}\text { Relationship with other } \\
\text { plans }\end{array}$ & Training in the use of the plan & Trigger levels \\
\hline
\end{tabular}

\section{Discussion of the results}

To compare the plans with the requirements of emergency planners both the metric scores and stakeholder survey scores were normalised. Figures 4 and 5 show the difference between the normalised stakeholder survey and metric scores for "Objectives, assumptions and target audiences"; "Organization and responsibility"; and "Communication". The lower the score the further away the metric is from meeting stakeholders' expectations. A very low score (e.g. -0.6) indicates a considerable gap between the stakeholders' requirements and what is actually in the plan and a positive score indicates that the stakeholders' expectations have been exceeded by the plan. Figure 4 shows that in terms of "Objectives, assumptions and target audiences" and "Organization and responsibility" the plans reviewed went a long way to meeting the stakeholders' requirements. Metrics related to implementation of plans and organisation such as "plan activation"; "actions, roles and responsibilities", "flood warning"; "target audience and updating"; and "aims and objectives" scored well in all three countries. Many stakeholders who took part in the research indicated that it was important to have roles and responsibilities well defined in flood emergency plans for different levels of flooding. The scores of these metrics would indicate that in general emergency planners are covering these subjects well.

Figure 5 shows that in terms of "communication" the French flood emergency plans generally scored the best. This may be that unlike England and Wales, and the Netherlands, there is a requirement for French plans to be in the public domain. Relationships with complementary plans and communication with other agencies scored relatively well; however, it was clear that there is room for improvements in the plans with regards to communication with the media.

Figure 6 shows the different normalised scores for seven metrics related to "Flood hazard"; "Receptors"; and "Evacuation" compared with the normalised scores for the required level of detail as perceived by the stakeholders. The perceived "level of detail" of information on: flood risk to people; flood risk to property; critical infrastructure; evacuation; NaTechs; shelters; and flood maps is similar in all three countries. However, the metric scores for the three countries are low indicating that there is a discrepancy between the level of detail required by the stakeholders on these issues and the information that is actually provided in emergency plans. In the 2007 floods in England and Wales the emergency response was hampered as a result of an inadequate understanding of: the location of critical infrastructure sites; the mapping of their vulnerability to flooding; and the consequences of their loss (Pitt, 2007).

In the Netherlands evacuation routes and times was seen as one of the most important pieces of information for plans. In January 1995 some 250,000 people had to be evacuated in the Netherlands as a result of high water levels on the River Rhine and River Meuse (IDNR, 1996). As a result of this and the fact that the Netherlands is a low-lying country, with about $20 \%$ of its area and $21 \%$ of its population located below sea level (Centraal Bureau voor de Statistiek, 2008) and $67 \%$ of the land prone to flooding from the sea or the Rhine and the Meuse Rivers (ten Brinke et al, 2010), evacuation is higher up the emergency planning agenda in the Netherlands than in France, or England and Wales. 
The metrics indicated that there is a difference in the way that flood hazard is depicted in emergency plans between the countries. In France and the Netherlands the metric score for flood hazard maps were both in the "above average" range. This is because in France and the Netherlands the flood maps included in the plans often include the maximum flood depth and sometimes maximum flood velocity, whereas in England and Wales only the maximum flood extent is generally shown. Many stakeholders consulted as part of the research stated that maps showing maximum depths and velocities for different flood scenarios would be useful to them if they could be made available. In England and Wales it should be possible to produce such maps in areas where two dimensional hydraulic modelling has been carried out. Similarly in France there was a stated desire to have more detailed flood maps and also emergency plans that display different flood probabilities (e.g. the 1 in 30 or 1 in 50 year flood) rather than the 1 in 100 year hazard, which is often the case in France.

The Netherlands had the highest metric score for risk to people. This may be partly as a result of the fact that researchers in the Netherlands have pioneered methods to assess injuries and loss of life owing to flooding and that a sudden failure of flood defences could result in a large number of fatalities. In France and England and Wales there was "room for improvement" in the treatment of risk to people, particularly vulnerable groups.

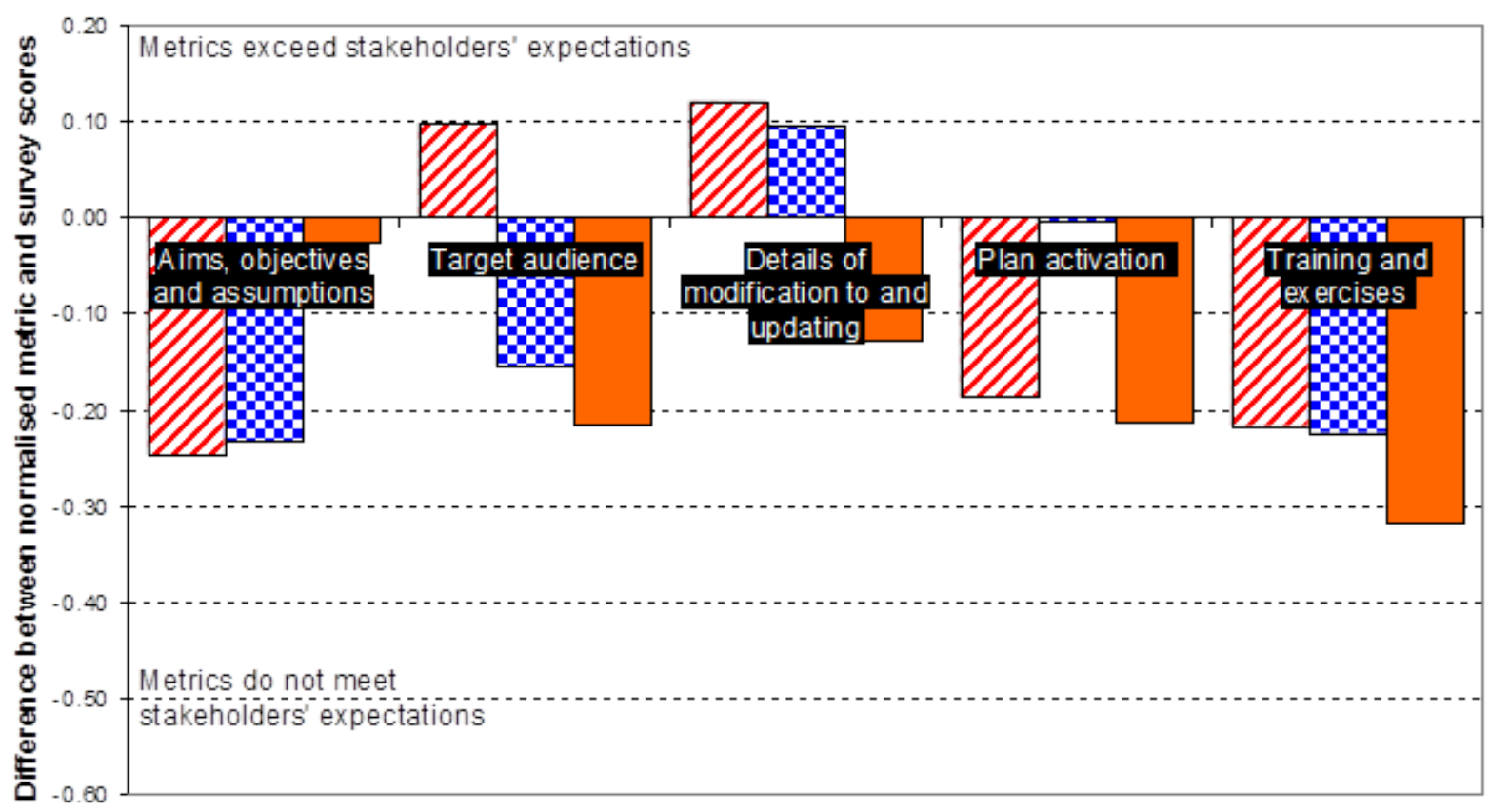

ఐEngland and Wales vFrance DThe Netherlands

Figure 4: Comparison of the difference between the normalised metric and stakeholder survey scores related to "Objectives, assumptions and target audiences" and "Organization and responsibility" 


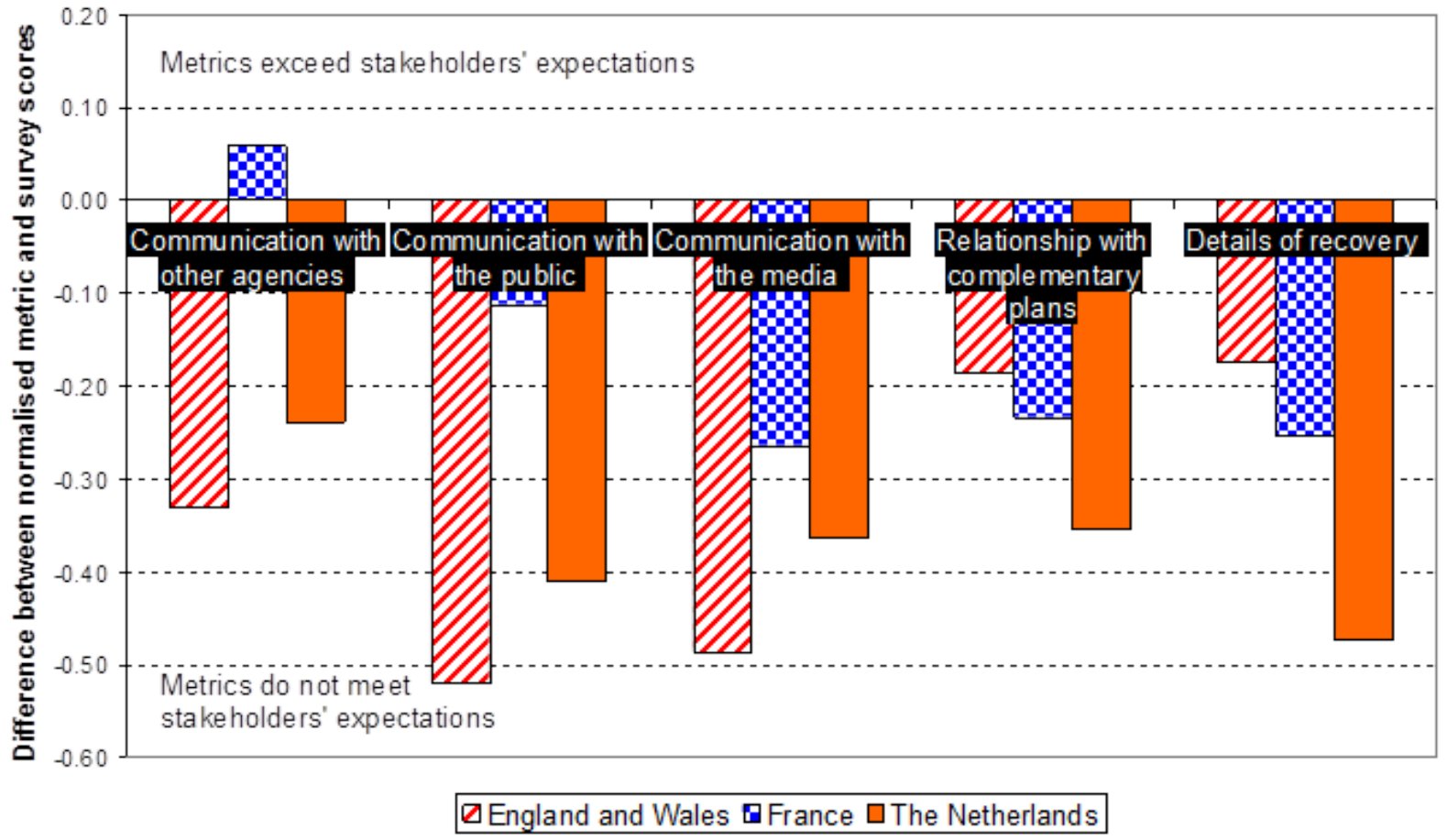

Figure 5: Comparison of the difference between the normalised metric and stakeholder survey scores related to "Communication"

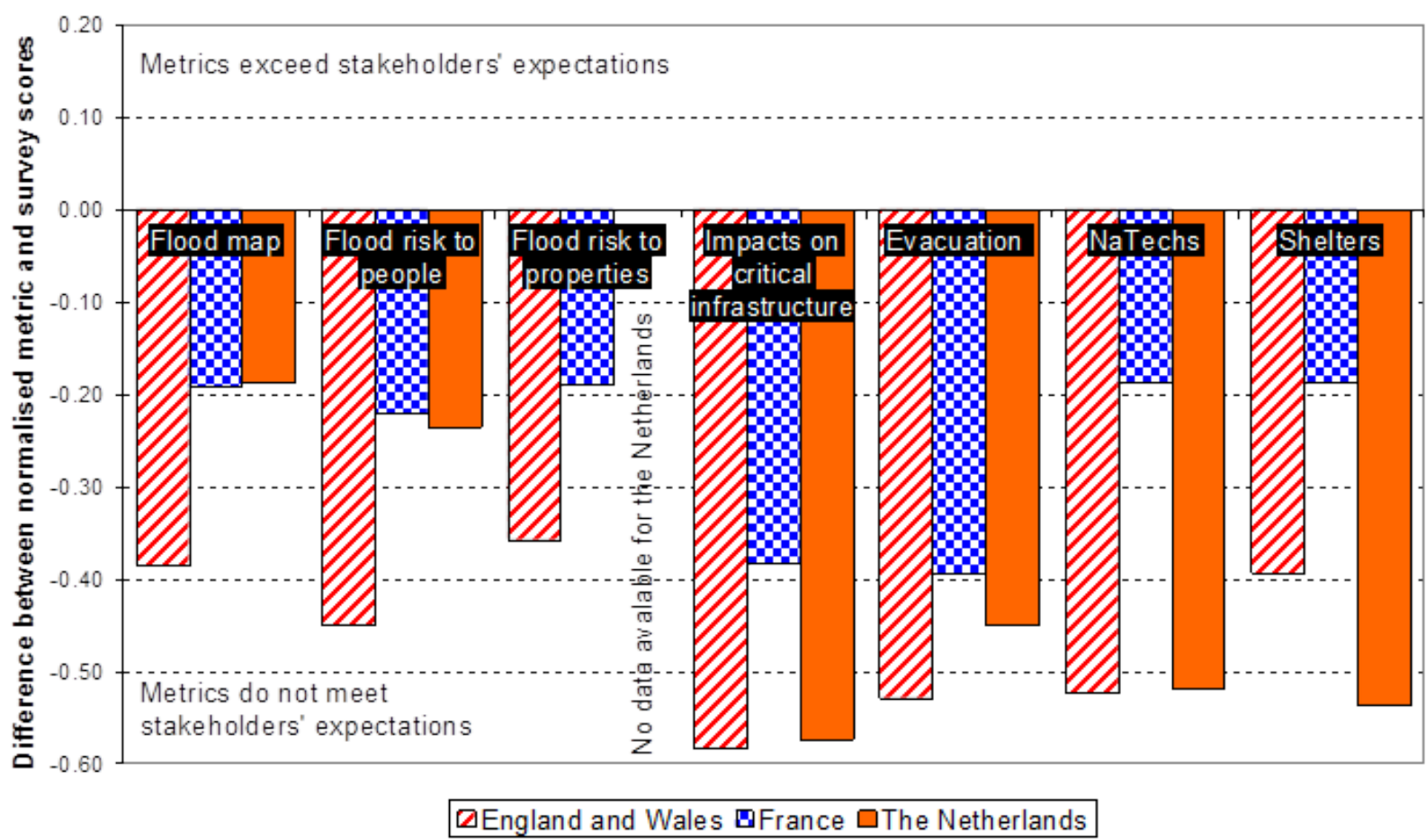

Figure 6: Comparison of the difference between normalised metric and stakeholder survey scores related to "Flood hazard", "Receptors" and "Evacuation" 
In all three countries there was a lack of information in the examined plans on critical infrastructure. However, it was clear from the research undertaken with the stakeholders that they viewed "potential damage to critical infrastructure" and the "interdependence between at risk critical infrastructure" (e.g. the failure of an electrical substation affecting a water treatment works) as being important information to include in emergency plans. However, this information was often not readily available to emergency planners.

In France, and England and Wales there was great emphasis given by the stakeholders on the accessibility of roads. The feedback on the emergency plan that was used recently in a recent large flood was that maps showing potential for road inundation outside the "formal flood maps" were of great use to emergency responders. In some regions of France methods are being developed specifically to assess the inundation of roads to assist emergency planners with their response.

In England and Wales there was only one plan that showed the location of industrial facilities in the floodplain. In France the metric for NaTech hazard scored higher than for the Netherlands and England and Wales; this is mainly because the PCS plans in France have a legal requirement to cover technological hazards. However, it is important to note that NaTech hazards are generally treated in isolation to other natural hazards in PCSs.

\section{Case study}

Cumbria is a non-metropolitan county in the north-west of England; in 2007 it had a total population of about 499,000. The county is bounded to the west by the Irish Sea. It is a predominantly rural area much of which is mountainous. In November 2009 Cumbria was subject to severe flooding. The rain gauge at the town of Seathwaite in Cumbria measured $314 \mathrm{~mm}$ of rainfall in 24 hours, which is equivalent to about a 1 in 500 year $(0.2 \%$ annual probability) rainfall event. A total of 2,240 properties were flooded throughout Cumbria. Infrastructure was badly affected with eight bridges destroyed by floodwater and a further 1,800 closed for inspection (Rodda, 2010).

The Cumbria MAFP was reviewed as part of this work just before the November 2009 flood event occurred using the 22 metrics that have been developed. Using these metrics the plan was rated as "Above average", scoring 2.3. In February 2010 the use of the plan in the November 2009 floods was reviewed by the Local Resilience Forum (LRF). The plan was used by responders and at the Cumbria police headquarters. 'The Risk of Flooding' section was the most used section of the plan by responders and at the incident command centre. There were positive comments about the information on the maps particularly the local infrastructure, location of electricity sub-stations and care homes. Flooding "hot-spots" and roads with a flooding history outside the formal flood warning areas in the county were also seen as very useful both to strategic and tactical response (Cumbria LRF, 2010).

In terms of 'Actions Roles and Responsibilities' the response and resource forms in the plan were seen as useful and gave at a quick glance what resources responders possessed (i.e. manpower, sandbags, plant). Overall the plan was seen to "knit together" with complementary plans in Cumbria with the only duplication being with the roles and responsibilities section for 'Major Incidents', although the MAFP focuses more on roles and responsibilities with regard to flooding (Cumbria LRF, 2010). Despite being 300 pages long the plan was found to be "compact and information was quite easy to locate" (Cumbria LRF, 2010). In terms of negative comments, maps in the plan were not perceived to be large enough and there was a need to ensure incident rooms were pre-supplied with a suite of larger maps which could be annotated. It was also felt that flood maps could be extended beyond flood warning areas (Cumbria LRF, 2010). 
The strengths of the MAFP picked out by the Cumbria LRF review of the plan were also identified by the review carried out as part of the research using the developed metrics. The following metrics: "Aims and objectives"; "Target audience and updating"; "Details of previous floods"; "Relationship with complementary emergency plans"; "Plan activation"; "Actions, roles and responsibilities"; and "Recovery" were all rated as being "good". The review using the metrics also picked up that although there were flood hazard maps in the MAFP, and that the maps showed roads prone to inundation outside the formal Environment Agency Flood Map, there was still room for improvement in these maps. The accordance of the metrics with the review carried out by the Cumbria LRF provides evidence that the metrics are of use in assessing flood emergency plans and identifying areas where they can be improved to reduce the "information gap" in MAFPs.

\section{Conclusions}

The metrics developed as part of the research have proved to be a useful tool for assessing emergency plans and providing a basis to allow comparison of the plans. There will always be some subjectivity involved when applying the metrics; however, the metrics in the context of this research provide a basis to map the following:

Where improvements can be made in the plans

- Requirements of the stakeholders

It is important to recognise that any metrics need to be revisited and possibly revised periodically either to take account of new circumstances or to adjust to the requirements of stakeholders.

There was found to be a discrepancy between the level of detail required by emergency planners and the actual level of detail that is available within emergency plans for a number of issues. This discrepancy is smaller for the metrics related to communication and organisation. It can therefore be concluded that the emergency plans do not comply with the requirements on issues related to receptors such as critical infrastructure, people and buildings.

The effectiveness of an emergency plan is a difficult entity to measure and several stakeholders indicated that this can only truly be assessed accurately after the plan has been used in a flood. Many emergency planners stated that a well defined description of the roles, responsibilities and communication is essential for a plan to be effective and these aspects tend to be well covered in the three countries looked at. However, other more technical aspects such as accessibility of roads during floods, evacuation, and the depiction of flood hazard and impacts of floods on critical infrastructure can be considerably improved. To conclude the main challenge for emergency planners is to avoid filling plans with generic text and to provide an appropriate level of specific detail in the plan whilst ensuring the usability of the plan.

\section{Recommendations}

It is important that once a flood emergency plan has been prepared it is treated as an ever-evolving document. It should be maintained systematically to ensure it remains up-to-date and fit for purpose. A regular screening of the plan using the developed metrics should be considered "good practice" for those who prepare or apply such plans. It is recommended that when emergency plans for floods are being formulated the "information gap" between what primary stakeholders require during a flood emergency and what is actually in the plan is assessed by applying the metrics developed as part of this research. It is recognised that the development of metrics to assess flood emergency plans is also an ongoing process. In 
the future, lessons learnt from where plans have been used to respond to large floods events should be used to further improve the metrics.

\section{Acknowledgements}

This research was carried out as part of the Flood Incident Management - A FRAMEwork for improvement (FIM FRAME) project carried out as part of the second ERA-Net CRUE funding initiative (http://www.crueeranet.net/). The project is funded by the joint Department for Environment, Food and Rural Affairs (Defra)/Environment Agency Flood and Coastal Erosion Risk Management Research and Development Programme in England and Wales and the Ministère de l'Ecologie, de l'Energie, du Développement durable et de la Mer, en charge des Technologies vertes et des Négociations sur le climat in France. We wish to acknowledge the support of the both the funders, the emergency responders who participated in this research and the comments of the reviewers. This work would also not have been possible without the Royal Academy of Engineers (RAEng) who provided a Global Research award to one of the authors. We wish to extend our thanks to the RAEng for their support.

\section{References}

Albrecht, S (1996) Crisis management for corporate self defence, Amacon, New York

Alcamo, J. Moreno, J.M., Nováky, B., Bindi, M., Corobov, R.; Devoy, R.J.N., Giannakopoulos, C., Martin, E., Olesen, J.E. and Shvidenko, A. (2007) Europe. Climate change 2007: Impacts, adaptation and vulnerability, Contribution of Working Group II to the Fourth Assessment Report of the Intergovernmental Panel on Climate Change, Cambridge Press, Cambridge, UK pp. 541-580

Alexander D (2002) Principles of emergency planning and management, Terra Publishing, Harpenden and Oxford University Press, New York

Alexander D (2003) Towards the development of a standards in emergency management training and education, Disaster Prevention and Management Vol. 12 No. 2 pp 113-123

Alexander D (2005) Towards the development of a standard in emergency planning, Journal of Disaster Prevention and Management Vol.14 No. 2, 2005

Association of British Insurers (ABI) (2007) Summer floods 2007: Learning the lessons, November 2007

Australian Government (2009) Emergency management planning for floods affected by dams, Manual 23, Australian Emergency Manuals Series

Barton, L. (1993) Crisis in organisations: Managing and communicating in the heat of chaos, South-Western, Cincinnati

Bereens, R. and Schneider, P. (2009) EU FloodEx 2009 Field exercise evaluation report November 2009 Available at: http://www.floodex.nl/about-floodex/evaluation

British Broadcasting Corporation (BBC) (2010) French flash flood toll up to 25, 17 June 2010, http://www.bbc.co.uk/news/10337433 (Accessed 6 September 2010)

ten Brinke, W.B.M., Bannick, B.A. and Ligtvoet, W. (2008) The evaluation of flood risk management policy in the Netherlands, Journal of Water Management, Volume 151, Number 4, pp93-102 
ten Brinke, W.B.M., Kolen, B, Dollee, A., van Waveren, H. and Wouters, K. (2010) Contingency planning for large floods in the Netherlands, Journal of Contingencies and Crisis Management, Volume 18, Number 1, March 2010

Centraal Bureau voor de Statistiek, The Netherlands (2008) Milieurekeningen 2008 Available at http://www.cbs.nl/NR/rdonlyres/D2CE63F9-D210-4006-B68B-98BE079EA9B6/0/2008c167pub.pdf Accessed 1 July 2010

Crews, D.T. (2001) The case for emergency management as a profession Australian Journal of Emergency Management Vol 16 No. 2 pp 2-3

Cumbria Local Resilience Forum (LRF) (2010) Use of Multi Agency Flood Plan in the November 2009 Cumbria Floods, Cumbria LRF Flood Planning Sub-Group, 3 February 2010

Department for the Environment Food and Rural Affairs (DEFRA) (2010) The national flood emergency framework for England Available at

http://www.defra.gov.uk/environment/flooding/documents/planning/emergency-framework-290710.pdf

Direction De La Defense Et De La Securitie Civiles (2004) Plan Communal de Sauvegarde - Guide Practique D'Elaboration

http://www.interieur.gouv.fr/sections/a I interieur/defense et securite civiles/gestion-risques/guidepratique-elaboration

Drabek, T. E. And Hoetmer, G. J. (1991) Emergency management: Principles and practice for local government, International City Management Association, Washington DC, USA

Drouet, N. (1982) Mobile medical emergency units in France - Part 1, British Medical Journal, Vol 284,26 June 1982

Dymon, U.J. (2003) An analysis of emergency map symbology, International Journal of Emergency Management Volume 1, No. 3, 2003

Enjolras, G., Erdlenbruch, K., Grelot, F., Kast, R., Thoyer, S. (2008) Flood management at the basin level in France: Sustainability of local risk-sharing policies World Water Congress 2008 Available at http://www.worldwatercongress2008.org/resource/authors/abs612 article.pdf

Environment Agency/Defra (2004) Exercise Triton 04: Overview report of lessons identified Available at: http://publications.environment-agency.gov.uk/pdf/GEHO0305BIRQ-e-e.pdf

Environment Agency/DEFRA (2008) Developing a Multi-Agency Flood Plan (MAFP) Guidance for Local Resilience Forums and Emergency Planners February 2008 version 4.4

Environment Agency (2009a) Flooding in Wales: A national assessment of flood risk

Environment Agency (2009b) Flooding in Wales: A national assessment of flood risk

Environment Agency/DEFRA/Civil Contingencies Secretariat (2009) Checklist for Multi-Agency Flood Plans (MAFP) 15 December 2009

European Environment Agency (2005) Vulnerability and adaptation to climate change in Europe EEA Technical report no $7 / 2005$

European exchange circle on flood forecasting (EXCIFF) (2007) Good practice for delivering flood-related information to the general public Available at: http://exciff.jrc.ec.europa.eu/downloads/exciff-relateddocuments/EXCIFF guide.pdf 
European exchange circle on flood mapping (EXIMAP) (2007) Handbook on good practices for flood mapping in Europe Available at:

http://ec.europa.eu/environment/water/flood risk/flood atlas/pdf/handbook goodpractice.pdf

Fischer III, H.W. (1996) What emergency management officials should know to enhance mitigation and effective disaster response, Journal of contingencies and crisis management Volume 4, Number 4, December 1996

Foster, A. (2010) Personal communication with Angela Foster June 2010, Flood and Coastal Risk Management Flood Response Policy, Environment Agency, England and Wales

Gruntfest, E. and Handmer, J. (2001) Coping with flash floods NATO science series, Kluwer Academic Publishers, $322 \mathrm{p}$.

Hayden, P. (2009) EU FloodEx 2009 UK evaluation report flood rescue and flood rescue management, Flood rescue and flood rescue management, Available at: http://www.hwfire.org.uk/PDF/news/FloodEx\%20UK\%20Report\%20-Issued\%2025-03-2010.pdf

Heath, R. (1998) Looking for answers: Suggestions for improving how we evaluate crisis management, Safety Science 30 (1998) 151-163

Hernu, H., Casteigts, M., Kbaier, R., Furst, X., Julien, B., Rochard, J., Balay, L-P. and Guillet, M. (2010) Rapport sur l'évaluation des dommages causes par la tempête Xynthia des 27 et 28 février 2010 à prendre en compte au titre du fond solidarité de l'Union Européenne, June 2010 Ministère De L'Ecologie, De L'Énergie, Du Développement Durable Et De La Mer http://agriculture.gouv.fr/IMG/pdf/Rapport 10087 dommage cause par xynthia.pdf

HM Government (2006) Evacuation and shelter guidance: Non-statutory guidance to complement emergency preparedness and emergency response and recovery, UK Government, October 2006 International Decade For Disaster Reduction (IDNR) (1996) Cities at risk - Making cities safer Before disaster strikes http://helid.desastres.net/en/d/Jdnd26e/1.html Accessed 1 July 2010

Jonkman, S.N., Stive, M.J.F. and Vrijling, J.K. (2005) New Orleans is a lesson to the Dutch, Journal of Coastal Research, Volume 21, Number 6, pp XI-XII

Jonkman, S.N. (2007) Loss of life estimation in flood risk assessment, PhD thesis, Delft University of Technology, the Netherlands

Lagadec, P. (2002) Crisis management in France: Trends, shifts and perspectives, Journal of Contingencies and Crisis Management, Volume 10, Number 4, December 2002

Lagadec P. and Guilhou X. (2002) La fin du risqué zéro, Eyrolles société - Les échos éditions, 316 pages, Paris

MacFarlane, R. (2005). A Guide to GIS applications in integrated emergency management, Emergency Planning College, Cabinet Office, UK

Marsh, T. J. and Hannaford, J. (2007) The summer 2007 floods in England and Wales - a hydrological appraisal Centre for Ecology \& Hydrology. 32pp. ISBN: 978-0-9557672-4-1

McConnell, A. and Drennan, L. (2006) Mission impossible? Planning and preparing for crisis, Journal of Contingencies and Crisis Management, Volume 14, Number 2, June 2006 
O'Brien, G. and Read, P. (2005) Future UK emergency management: new wine, old skin? Disaster Prevention and Management Vol. 14 No. 3, 2005 pp. 353-361

Pitt, M. (2008) Learning lesson from the 2007 floods Available at http://archive.cabinetoffice.gov.uk/pittreview/thepittreview/final report.html

Pottier, N; Penning-Rowsell, E., Tunstall, S. and Hubert, G. (2005) Land use and flood protection: contrasting approaches and outcomes in France and in England and Wales Applied Geography 25 (2005) 127

Poulard, C (2009) La prévention des inondations: Aspects techniques et économiques des aménagements de ralentissement dynamique des crues, ISBN 978-2-85362-677-4, July 2009

Pratchett, L. (2004) Coping with crisis: Lesson drawing from emergency planning in the UK, Paper presented at Worldwide Universities Public Policy Network Workshop (Strategic Management in urban government), 29-30 October 200', Zhejiang, China

Rodda, H.J. (2010) Extreme precipitation and flooding in NW England and SW Scotland: November 2009, Event Science Report 01, Benfield Hazard Research Centre

Tapsell S. and Ball, D. J. (2007). Flood event management, Chapter 20, in Future flooding and coastal erosion risk, ed. C. Thorne, E.P. Evans, E.C. Penning-Rowsell, Thomas Telford Services Ltd

Tricot, A (2008) La prévention des risques d'inondation en France: Entre approche normative de l'état et expériences locales des cours d'eau, Environnement Urbain, Vol. 2, 2008, p. 123-133.

Tunstall, S.M., Johnson, C.L. and Penning Rowsell, E.C. (2004) Flood hazard management in England and Wales: From land drainage to flood risk management, World Congress on Natural Disaster Mitigation 19-21 February 2004

Younge, P. (2005) Exercise Triton 04 - Lessons from the UK largest flood scenario, Blueprint: The magazine of the Emergency Planning Society, Autumn, pp 10-11

http://webarchive.nationalarchives.gov.uk/20070305164040/http://hm-

treasury.gov.uk/spending review/spend sr04/report/spend sr04 repindex.cfm 


\section{Appendices}

\section{A. Generic metrics for the assessment of flood emergency plans in England and Wales, France and the Netherlands - Part 1}

\begin{tabular}{|c|c|c|c|}
\hline \multirow[b]{2}{*}{ Metric } & \multicolumn{3}{|c|}{ Level of detail } \\
\hline & Low & Medium & High \\
\hline \multicolumn{4}{|c|}{ Objectives, assumptions and target audience } \\
\hline Aims and objectives of plan & $\begin{array}{l}\text { Not } \\
\text { detailed }\end{array}$ & $\begin{array}{l}\text { Aims and } \\
\text { objectives } \\
\text { included but could } \\
\text { be clarified further }\end{array}$ & $\begin{array}{l}\text { Clearly stated aims and objectives } \\
\text { including the area covered, types } \\
\text { and sources of flooding }\end{array}$ \\
\hline $\begin{array}{l}\text { Target audience and updating } \\
\text { of the plan }\end{array}$ & $\begin{array}{l}\text { Not } \\
\text { detailed }\end{array}$ & $\begin{array}{l}\text { Audience defined } \\
\text { and plan dated }\end{array}$ & $\begin{array}{l}\text { Audience defined and how } \\
\text { they will be notified of updates and } \\
\text { modifications to the plan included }\end{array}$ \\
\hline Assumptions made by the plan & $\begin{array}{l}\text { Not } \\
\text { detailed }\end{array}$ & $\begin{array}{l}\text { Covers some } \\
\text { aspects }\end{array}$ & $\begin{array}{l}\text { Covers all aspects including: flood } \\
\text { warning lead time; method by which } \\
\text { rescue will be undertaken; } \\
\text { implications of the failure of critical } \\
\text { infrastructure }\end{array}$ \\
\hline \multicolumn{4}{|c|}{ Organisation and responsibilities } \\
\hline $\begin{array}{l}\text { Actions, roles and } \\
\text { responsibilities }\end{array}$ & $\begin{array}{l}\text { Not } \\
\text { detailed }\end{array}$ & $\begin{array}{l}\text { Brief details of the } \\
\text { roles and } \\
\text { responsibilities } \\
\text { related to the } \\
\text { activation of the } \\
\text { plan provided }\end{array}$ & $\begin{array}{l}\text { Details of the roles and } \\
\text { responsibilities related to the } \\
\text { activation of the plan provided } \\
\text { including health and safety and } \\
\text { environmental considerations }\end{array}$ \\
\hline Recovery & $\begin{array}{l}\text { Not } \\
\text { detailed }\end{array}$ & $\begin{array}{l}\text { Brief details of } \\
\text { how the recovery } \\
\text { is managed }\end{array}$ & $\begin{array}{l}\text { Details of how the recovery is } \\
\text { managed including clean up, waste } \\
\text { disposal, repairs to public assets, } \\
\text { humanitarian assistance }\end{array}$ \\
\hline Training and exercises & $\begin{array}{l}\text { Not } \\
\text { detailed }\end{array}$ & $\begin{array}{l}\text { Brief details of } \\
\text { training and } \\
\text { exercise } \\
\text { requirements }\end{array}$ & $\begin{array}{l}\text { Internal and external (with other } \\
\text { organisations) training and } \\
\text { exercises outlined }\end{array}$ \\
\hline Plan activation & $\begin{array}{l}\text { Not } \\
\text { detailed }\end{array}$ & $\begin{array}{l}\text { Brief description } \\
\text { of the thresholds } \\
\text { or levels used to } \\
\text { activate plan }\end{array}$ & $\begin{array}{l}\text { Description of the thresholds or } \\
\text { levels used to activate plan together } \\
\text { with flow chart }\end{array}$ \\
\hline
\end{tabular}




\begin{tabular}{|l|l|l|l|}
\hline Metric & \multicolumn{2}{l}{ Level of detail } & \\
\hline $\begin{array}{l}\text { Communication } \\
\text { Communication with other } \\
\text { agencies }\end{array}$ & $\begin{array}{l}\text { Not } \\
\text { detailed }\end{array}$ & Outlined in words & $\begin{array}{l}\text { Detailed and the links shown } \\
\text { diagrammatically }\end{array}$ \\
\hline $\begin{array}{l}\text { Communication with the public } \\
\text { Mot } \\
\text { detailed }\end{array}$ & Outlined in words & $\begin{array}{l}\text { Detailed and shown the links shown } \\
\text { diagrammatically }\end{array}$ \\
\hline Flood warning (if available) & $\begin{array}{l}\text { Not } \\
\text { detailed }\end{array}$ & $\begin{array}{l}\text { Not } \\
\text { Outline media } \\
\text { management } \\
\text { strategy in place }\end{array}$ & $\begin{array}{l}\text { Well defined media management } \\
\text { strategy in place }\end{array}$ \\
\hline $\begin{array}{l}\text { Levels of flood } \\
\text { warning with } \\
\text { details of the } \\
\text { areas flooded at } \\
\text { each level }\end{array}$ & $\begin{array}{l}\text { Levels of flood warning with details } \\
\text { of the areas flooded at each level } \\
\text { and shown on a map }\end{array}$ \\
\hline $\begin{array}{l}\text { Relationship with } \\
\text { complementary emergency } \\
\text { plans detailed }\end{array}$ & $\begin{array}{l}\text { Not } \\
\text { detailed }\end{array}$ & Outlined in words & $\begin{array}{l}\text { Detailed and the links shown } \\
\text { diagrammatically }\end{array}$ \\
\hline
\end{tabular}




\section{A. Generic metrics for the assessment of flood emergency plans in England and Wales, France and the Netherlands - Part 2}

\begin{tabular}{|c|c|c|c|}
\hline \multirow[b]{2}{*}{ Metric } & \multicolumn{3}{|c|}{ Level of detail } \\
\hline & Low & Medium & High \\
\hline \multicolumn{4}{|l|}{ Evacuation } \\
\hline Evacuation routes & $\begin{array}{l}\text { Not } \\
\text { detailed }\end{array}$ & $\begin{array}{l}\text { Evacuation routes } \\
\text { shown on a map }\end{array}$ & $\begin{array}{l}\text { Evacuation routes detailed together } \\
\text { with roads likely to be closed and } \\
\text { their accessibility for emergency } \\
\text { vehicles and other vehicles }\end{array}$ \\
\hline Shelters/Safe havens & $\begin{array}{l}\text { Not } \\
\text { detailed }\end{array}$ & $\begin{array}{l}\text { Safe } \\
\text { havens/shelters } \\
\text { shown on a map }\end{array}$ & $\begin{array}{l}\text { Safe havens/shelters shown on a } \\
\text { map with their capacity and facilities }\end{array}$ \\
\hline \multicolumn{4}{|l|}{ Flood hazard } \\
\hline Flood hazard map & $\begin{array}{l}\text { Not } \\
\text { detailed }\end{array}$ & $\begin{array}{l}\text { Flood hazard } \\
\text { map(s) showing } \\
\text { extent }\end{array}$ & $\begin{array}{l}\text { Flood hazard map(s) showing water } \\
\text { depth and velocity }\end{array}$ \\
\hline $\begin{array}{l}\text { Details of previous floods (if } \\
\text { available) }\end{array}$ & $\begin{array}{l}\text { Not } \\
\text { detailed }\end{array}$ & $\begin{array}{l}\text { Brief description } \\
\text { of historical flood }\end{array}$ & $\begin{array}{l}\text { Description of historical floods with } \\
\text { the cause and a brief description of } \\
\text { the risk in terms of people and } \\
\text { properties affected }\end{array}$ \\
\hline \multicolumn{4}{|l|}{ Flood risk to receptors } \\
\hline Flood risk to people & $\begin{array}{l}\text { Not } \\
\text { detailed }\end{array}$ & $\begin{array}{l}\text { Number of people } \\
\text { potentially } \\
\text { affected included }\end{array}$ & $\begin{array}{l}\text { Potential injuries and loss of life } \\
\text { included and mapped for a range of } \\
\text { scenarios }\end{array}$ \\
\hline $\begin{array}{l}\text { Flood risk to vulnerable people } \\
\text { (e.g. elderly or disabled) }\end{array}$ & $\begin{array}{l}\text { Not } \\
\text { detailed }\end{array}$ & $\begin{array}{l}\text { Areas where } \\
\text { elderly/sick } \\
\text { people live } \\
\text { mapped }\end{array}$ & $\begin{array}{l}\text { Numbers of vulnerable people } \\
\text { defined with a response strategy }\end{array}$ \\
\hline $\begin{array}{l}\text { Flood risk to residential } \\
\text { property }\end{array}$ & $\begin{array}{l}\text { Not } \\
\text { detailed }\end{array}$ & $\begin{array}{l}\text { Number of } \\
\text { properties defined }\end{array}$ & $\begin{array}{l}\text { Number of properties defined } \\
\text { together with those at risk of } \\
\text { collapsing during an extreme flood }\end{array}$ \\
\hline Flood risk to businesses & $\begin{array}{l}\text { Not } \\
\text { detailed }\end{array}$ & $\begin{array}{l}\text { Number of } \\
\text { businesses } \\
\text { defined }\end{array}$ & $\begin{array}{l}\text { Number and type of businesses } \\
\text { defined together with potential } \\
\text { losses }\end{array}$ \\
\hline $\begin{array}{l}\text { Flood risk to critical } \\
\text { infrastructure (e.g. water } \\
\text { supply, gas, electricity, police, } \\
\text { fire brigade) }\end{array}$ & $\begin{array}{l}\text { Not } \\
\text { detailed }\end{array}$ & $\begin{array}{l}\text { Number of pieces } \\
\text { of critical } \\
\text { infrastructure } \\
\text { shown on the } \\
\text { flood map(s) }\end{array}$ & $\begin{array}{l}\text { Number of pieces critical } \\
\text { infrastructure shown on the flood } \\
\text { map(s) and an assessment of their } \\
\text { likelihood of failure during a flood }\end{array}$ \\
\hline
\end{tabular}




\begin{tabular}{|l|l|l|l|}
\hline Metric & \multicolumn{2}{|l}{ Level of detail } \\
$\begin{array}{l}\text { Potential for NaTech hazards at } \\
\text { industrial facilities (if present) }\end{array}$ & $\begin{array}{l}\text { Not } \\
\text { detailed }\end{array}$ & $\begin{array}{l}\text { Potential NaTech } \\
\text { sites shown on } \\
\text { map }\end{array}$ & $\begin{array}{l}\text { Potential NaTech sites shown on } \\
\text { site and brief details of the response }\end{array}$
\end{tabular}

*Note: A NaTech is defined as technological hazard that is triggered by a natural hazard. For example the flooding of an industrial plant may lead to the release of a toxic chemical that poses a threat to humans, as well as flora and fauna 